CASE REPORT

\title{
Relapse of Anterior Open Bite: A Case Report
}

Aline F Justulin ${ }^{1}$, Paulo H Rossato ${ }^{2}$, Ana CCF Conti ${ }^{3}$, Marcio R Almeida ${ }^{4}$, Paula Vanessa Pedron Oltramari ${ }^{5}$, Thais MF Fernandes ${ }^{6}$

\begin{abstract}
The aim and objective of this study is to report the recurrence of the treatment of the anterior open bite after 5 years of treatment. A female patient aged 8 years 6 months old had a negative vertical crossing of $-4.7 \mathrm{~mm}$. Early treatment with a fixed palatal grid was performed for 1 year. At the end of the treatment, the vertical overpass was $1.1 \mathrm{~mm}$ and after 2 years of control, the vertical overpass remained positive with $1.7 \mathrm{~mm}$ showing the stability of the treatment. After 5 years, and due to the sucking and lingual interposition habit, there was a recurrence of the open bite. Interdisciplinary follow-up is extremely important to eliminate the factors responsible for the origin of deleterious habits, thus solving the changes resulting from these habits and providing long-term stability.
\end{abstract}

Keywords: Interceptive orthodontics, Malocclusion, Open bite.

International Journal of Clinical Pediatric Dentistry (2021): 10.5005/jp-journals-10005-1893

\section{INTRODUCTION}

The anterior open bite (AOB) is characterized by the absence of vertical trespass between the upper and lower incisors. Its etiology is multifactorial, involving deleterious oral habits (digital sucking or pacifiers), lingual interposition, mouth breathing, among others. ${ }^{1-3}$ It leads to the compromising of masticatory, speech-language, and esthetic and psychological problems of children.

Anterior open bite is a malocclusion with a high prevalence, more frequent in the infant population, and reaches about $17 \%$ of children with mixed dentition. ${ }^{4,5}$ In children with prolonged sucking habits, the AOB is present in $78.5 \% .^{5}$ Some open bites when treated early are easily corrected with "recall" devices. ${ }^{4,6}$

The AOB was considered a difficult treatment because it was predisposed to relapses. ${ }^{3,7}$ Numerous studies and case reports have highlighted the efficacy of various treatment modalities available for the correction of $A O B$, but analysis of long-term stability has been rarely reported in the literature. ${ }^{8-10}$ In addition to orthodontic and orthopedic therapies, it is essential the behavioral changes. ${ }^{4}$ The risk of relapse of this malocclusion decreases when there is a multidisciplinary approach, with the participation of the orthodontist, speech therapist, and psychologist. $^{11}$

This study aims to present a clinical case of AOB intercepted early using the fixed palatal grid for a period of 1 year, treated successfully, and with stability after 2 years. However, 5 years after treatment, there was a recurrence of the open bite due to the return of the digital sucking habit.

\section{Case Description}

\section{History}

A female patient aged 8 years 6 months old, attended the Universidade Norte do Paraná to perform the early treatment of AOB. Parents reported that the child had the non-nutritive habit of digital sucking.

\section{Intraoral and Extraoral Assessment}

The patient presents facial symmetry, non-passive lip seal, and swallowing lingual interposition. The initial $A O B$ was $-4.7 \mathrm{~mm}$

\footnotetext{
${ }^{1-6}$ Department of Orthodontics, University of North Paraná, Londrina, Brazil
}

Corresponding Author: Thais MF Fernandes, Department of Orthodontics, University of North Paraná, Londrina, Brazil, Phone: +554399559165, e-mail: thaismaria@hotmail.com

How to cite this article: Justulin AF, Rossato $\mathrm{PH}$, Conti $A C C F$, et al. Relapse of Anterior Open Bite: A Case Report. Int J Clin Pediatr Dent 2021;14(1):140-144.

Source of support: Capes and Funadesp for concession of scholarships Conflict of interest: None

(Fig. 1). The patient had a mixed denture phase, with a complete eruption of the central incisors and first permanent molars, Angle Class I relationship, and absence of posterior crossbite (Fig. 1).

\section{Radiographic Assessment}

Based on the initial panoramic radiograph, the patient did not present with agenesis or supernumerary teeth. Cephalometric analysis showed adequate relation between apical bases (ANB = $\left.10.6^{\circ}\right)$ and vertical growth pattern (SN.GoGn $\left.=35.6^{\circ}\right)$, presented excessive inclination for vestibular of upper incisors (U1.NA $\left.=32.7^{\circ}\right)$ and lower $\left(\mathrm{L} 1 . \mathrm{NB}=37.9^{\circ}\right.$ ) (Table 1).

\section{Etiology}

The main cause of this malocclusion is attributed to the non-nutritive habit of digital suction together with the lingual interposition. He began to exhibit the digital sucking habit around the age of 5 . The mother reported that it was high intensity, approximately 18 hours daily.

\section{Treatment}

The proposed treatment was the use of fixed palatal grids with cemented bands with glass ionomer (Multi-Curere ${ }^{\circledR}$, Unitek/3M, Monrovia, CA, USA) in the first permanent maxillary molars, made with $0.9 \mathrm{~mm}$. The extension of the grid covered the entire $A O B$, preventing the interposition of the tongue, without interfering with the soft tissues and mandibular movements (Fig. 2). 


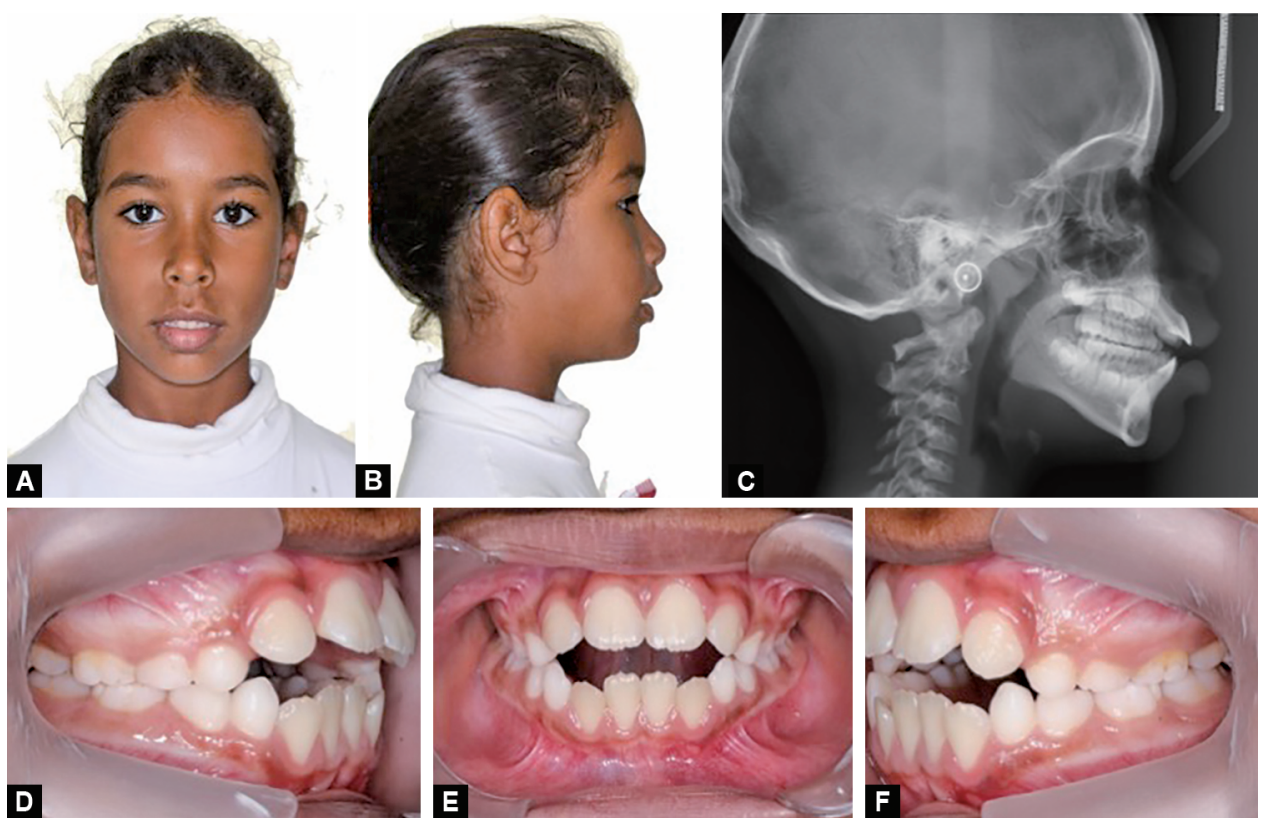

Figs $1 \mathrm{~A}$ to F: Front, lateral view, and cephalometric radiography. Side and front views at the beginning of treatment

At the end of treatment, after 12 months, the positive vertical overjet reached was $1.1 \mathrm{~mm}$. It can be noticed in the clinical and cephalometric aspects present in Figure 3 and in Table 1. After this period, the palatal grid was removed and maintained without the use of any containment device.

The control after 2 years detected $1.7 \mathrm{~mm}$ of vertical trespass, showing skeletal cephalometric measures normal, with stability and improvement in the vertical positioning of the incisors, but recurrence in the inclination of the incisors, especially in the lower segment (Fig. 4).

The control after 5 years detected a negative vertical overlap of $3.6 \mathrm{~mm}$, showing a recurrence of the AOB can be noticed by the clinical characteristics (Fig. 5) and also by the cephalometric measurements (Table 1) due to the return of the digital suction habit.

\section{Discussion}

Prolonged deleterious habits such as digital sucking and tongue interposition are strongly associated with children. Therefore, it is ideal to perform an early intervention to control permanent dentoskeletal changes. ${ }^{1}$

The objective of the present study was to evaluate the changes that occurred in the post-treatment period in two moments, after 2 years and 5 years. Several devices have been studied for the early treatment of $A O B,{ }^{12-14}$ with effective results in early treatment with favorable prognosis when deleterious oral habits are eliminated..$^{8,15-18}$ However, the stability of the results obtained is even an issue under discussion. ${ }^{19}$

The palatal grids are passive appliances and reminders that act as an obstacle to sucking habits and also to the contact of the tongue with the incisors. ${ }^{1}$ With the removal of the devices, there is a tendency to reposition and lingual contact with the incisors, leading to the recurrence of aggravated vestibular inclination when there is a return of deleterious habits. ${ }^{8,20}$ The reported case shows dent alveolar involvement, without craniofacial dysplasia, with the main etiological factors being suction and lingual interposition habits.
Table 1: Cephalometric measurements of the patient treated with fixed palatal grid

\begin{tabular}{|c|c|c|c|c|}
\hline Measures & Initial & Final & $\begin{array}{l}2 \text { years post- } \\
\text { treatment }\end{array}$ & $\begin{array}{l}5 \text { years post- } \\
\text { treatment }\end{array}$ \\
\hline SNA $\left(^{\circ}\right)$ & 87.0 & 84.8 & 84.2 & 85.5 \\
\hline $\mathrm{SNB}\left({ }^{\circ}\right)$ & 76.4 & 77.8 & 79.1 & 78.1 \\
\hline ANB $\left(^{\circ}\right)$ & 10.6 & 7.0 & 5.1 & 7.4 \\
\hline $\begin{array}{l}\text { Overbite } \\
(\mathrm{mm})\end{array}$ & -4.7 & 1.1 & 1.7 & -0.8 \\
\hline 1.NA $\left(^{\circ}\right)$ & 32.7 & 23.9 & 25.8 & 30.2 \\
\hline $1-\mathrm{NA}(\mathrm{mm})$ & 6.6 & 4.7 & 5.9 & 9.7 \\
\hline 1-PP (mm) & 21.0 & 24.5 & 25.9 & 24.9 \\
\hline $1 . \mathrm{NB}\left({ }^{\circ}\right)$ & 40.7 & 26.8 & 37.9 & 37.7 \\
\hline 1-NB (mm) & 8.6 & 7.1 & 10.5 & 11.1 \\
\hline 1-MP (mm) & 36.0 & 38.4 & 38.5 & 41.6 \\
\hline FMA $\left(^{\circ}\right)$ & 27.4 & 27.6 & 29.1 & 27.3 \\
\hline SN.GoGn $\left({ }^{\circ}\right)$ & 35.6 & 35.9 & 35.9 & 36.6 \\
\hline SN.Gn $\left({ }^{\circ}\right)$ & 69.2 & 70.1 & 70.1 & 70.6 \\
\hline Co-A (mm) & 75.2 & 81.9 & 82.3 & 82.3 \\
\hline Co-Gn (mm) & 100.3 & 103.4 & 106.7 & 110.4 \\
\hline $\begin{array}{l}\text { AFP/AFA } \\
(\%)\end{array}$ & 60.3 & 61.4 & 61.9 & 63.0 \\
\hline
\end{tabular}

These factors generate forces of relatively low magnitude and lead to morphological alterations in hard tissues, which are malleable, blocking the growth of the alveolar process and installing the AOB. ${ }^{21}$

The positive result of the treatment presented up to 2 years confirms the successful use of the palatal grid, already described in the literature. ${ }^{14,22-24}$ The correction and stability of the positive vertical overjet of the anterior teeth were achieved mainly by the dentoalveolar effects of extrusion of the (1-PP and 1-MP), showing a gradual increase of 1-PP (upper incisor-palatal plane) and 1-MP (lower incisor-mandibular plane) and abandonment of habits 

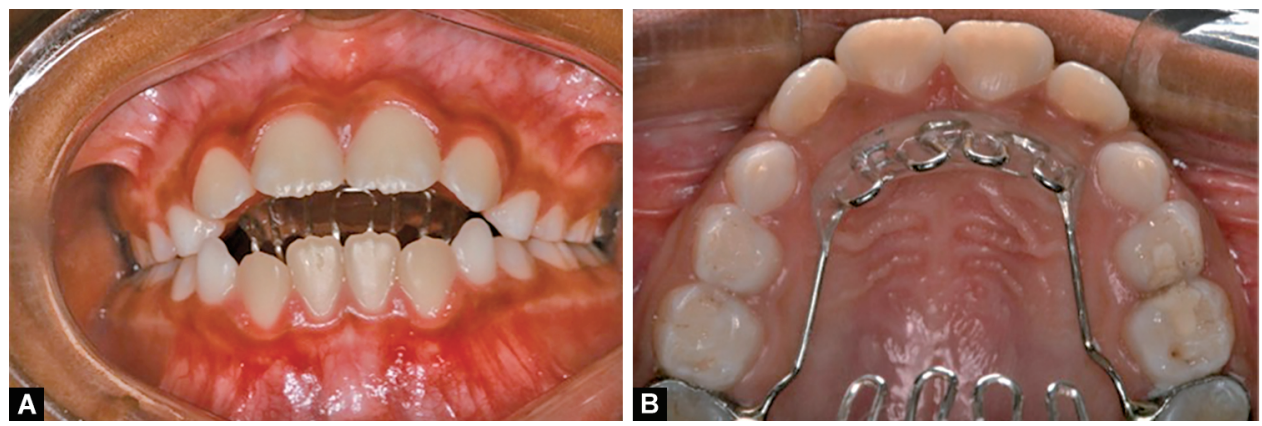

Figs $2 \mathrm{~A}$ and B: Frontal and occlusal views immediately after placement of the fixed palatal grid
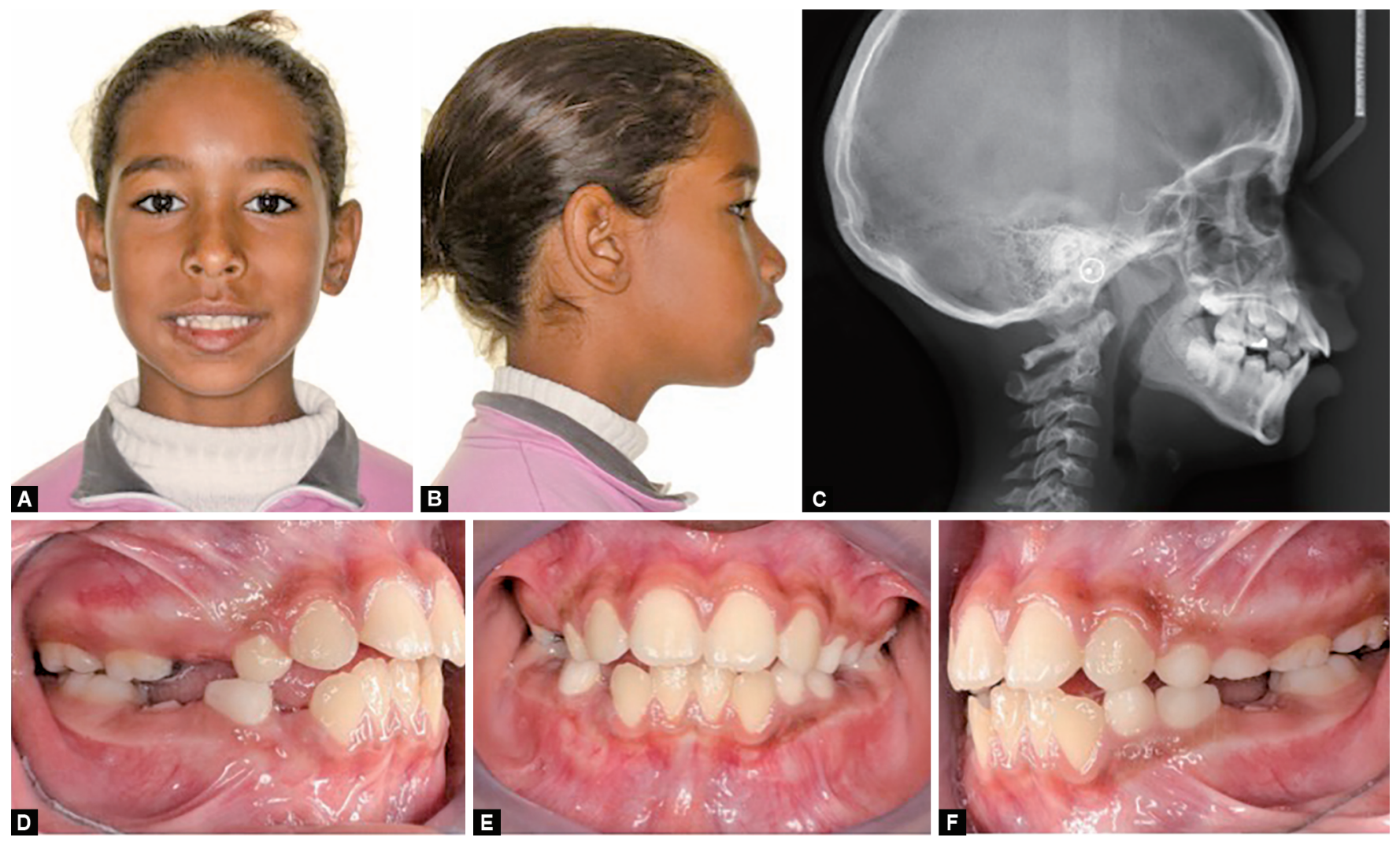

Figs $3 \mathrm{~A}$ to F: Front, lateral, and cephalometric radiography. Side and frontal views at the end of treatment

mouth disease in the treatment and post-treatment period of 2 years. However, the return of the sucking habit associated with lingual interposition leads to the recurrence of the treatment. The secondary lingual interposition, in which the tongue adapts to the morphological alteration caused by the digital sucking habit, results in the inclination of the upper and lower incisors, causing a space between them, causing the open bite. ${ }^{25}$ After 5 years of treatment, recurrence occurred in the presented clinical case. The craniofacial growth and development presented stable, but the vestibular inclination of the incisors demonstrated an increase of the measurements 1.NA $=30.2^{\circ} ; 1-\mathrm{NA}=9.7 \mathrm{~mm}, 1 . \mathrm{NB}=37.7^{\circ}$, and $1-\mathrm{NB}=11.1 \mathrm{~mm}$. Increased vertical overpass showing the opening of the anterior bite.

The deleterious habits become unconscious and are incorporated into the child's personality. ${ }^{26}$ Two behavioral theories were used to explain the etiology of oral habits. The theory of learning in which he believes is just a learned habit. And psychoanalytic theories in which children who do not abandon their habits present an indication of psychological disturbances. ${ }^{27-29}$ There is a strong correlation between deleterious habits and different disorders, especially those with anxiety symptoms. ${ }^{30}$

\section{Conclusion}

Early diagnosis and treatment of $A O B$ improve the position of anterior teeth, reflecting improved mastication, swallowing, speech, lip sealing, and self-esteem.

The outcome of treatment recurrence can be explained by the return of deleterious oral habits. These alter the position and inclination of the superior and inferior incisors causing recurrence of the treatment.

The multidisciplinary follow-up with the orthodontist, speech therapist, psychologist, and otorhinolaryngologist is fundamental to solve the changes resulting from these habits and achieve longterm stability. 

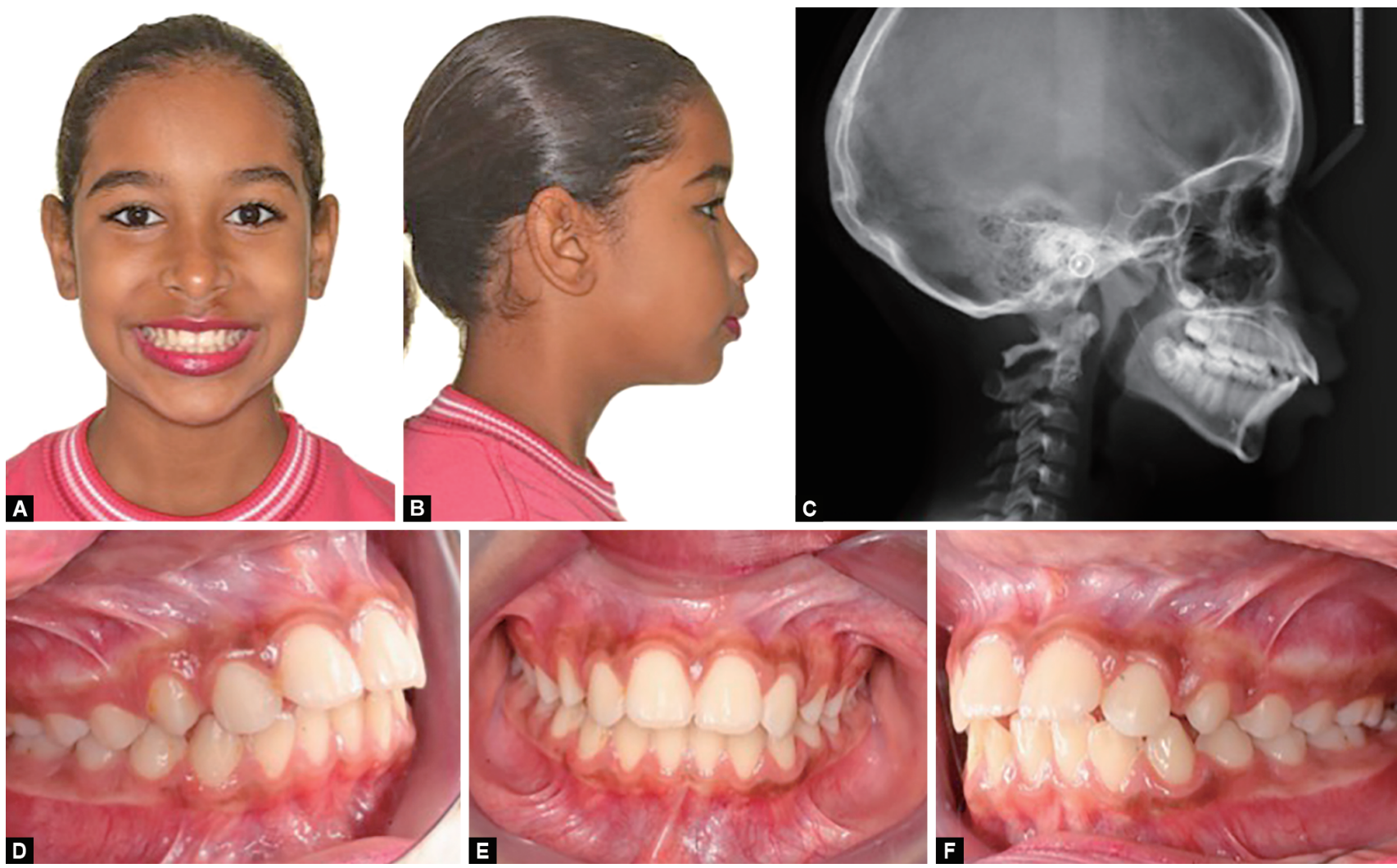

Figs 4A to F: Front, lateral view, and cephalometric radiography. Side and frontal views after 2 years of treatment
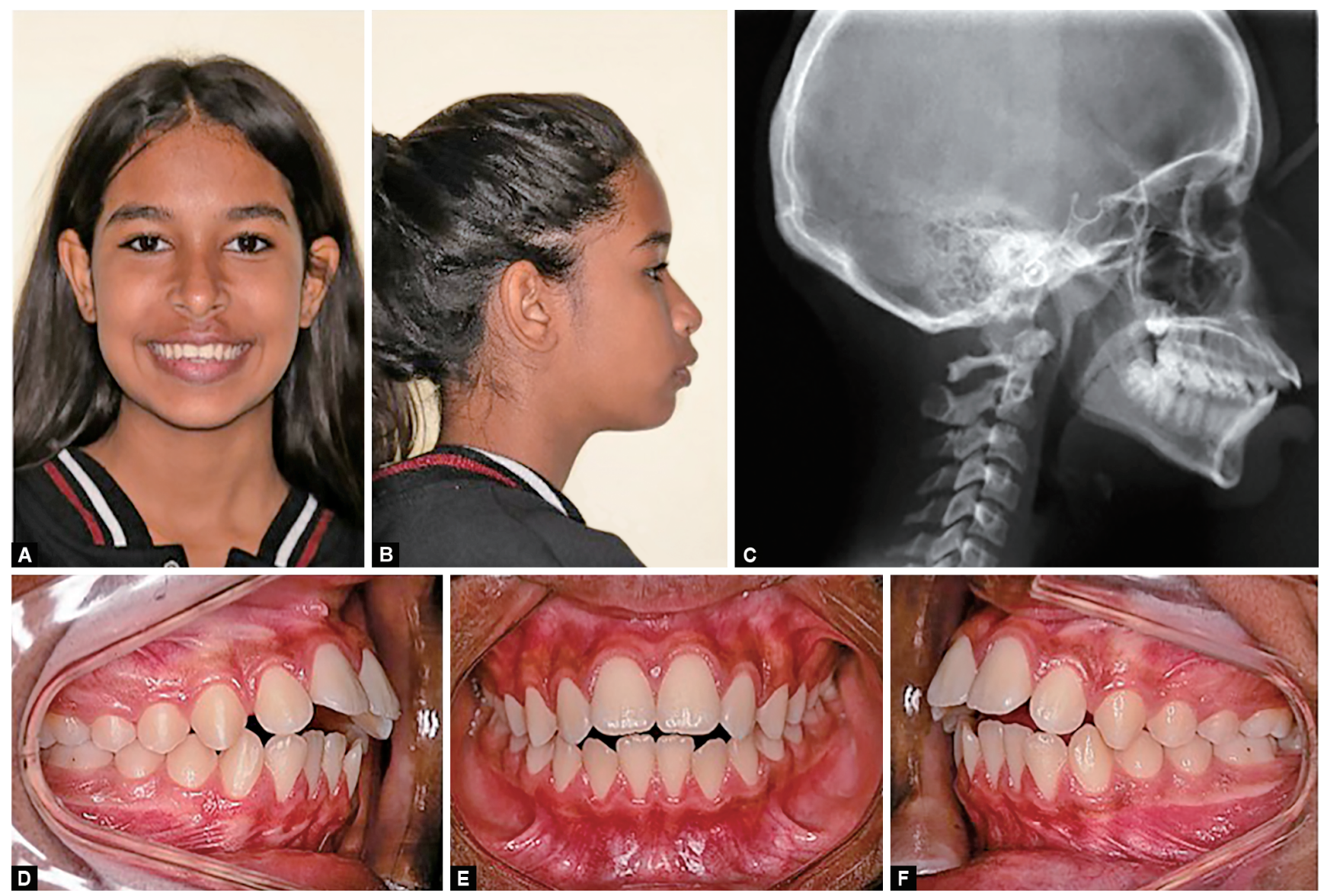

Figs 5 A to F: Front, lateral view, and cephalometric radiography. Side and frontal views after 5 years of treatment 


\section{References}

1. Almeida R, Almeida-Pedrin R, Almeida M, et al. Vertical dysplasias: anterior open bite treatment and stability. Revista Dental Press de Ortodontia e Ortopedia Facial 2003;8:91-119.

2. Almeida RRD, Almeida Pedrin RR, Almeida MRD, et al. Etiologia das más oclusöes: causas hereditárias e congênitas, adquiridas gerais, locais e proximais (hábitos bucais). Rev Dent Press Ortodon Ortop Maxilar 2000;5(6):107-129.

3. Subtelny JD, Sakuda M. Open-bite: diagnosis and treatment. American J Orthodont 1964;50(5):337-358. DOI: 10.1016/0002-9416(64)90175-7.

4. Almeida R, Henriques J, Almeida M, et al. Early treatment of anterior open bite-prevention of orthognatic surgery. Biological mechanisms of tooth eruption, resorption and replacement by implants. Boston: Harvard Soc Advance Orthod 1998. 585-588.

5. Silva Filho OG, Freitas SF, Cavassan AO. Prevalência de oclusão normal e má oclusão em escolares da cidade de Bauru (São Paulo). Parte II. Influência da estratificação sócio-econômica. Rev Odontol Univ São Paulo 1990;4(3):89-96.

6. Ozawa TO, Capelozza Filho L, Silva Filho OGD. Controle vertical em ortodontia com o uso de "bite block". Ortodontia 1998;31(2):81-90.

7. Lopez-Gavito G, Wallen TR, Little RM, et al. Anterior open-bite malocclusion: a longitudinal 10-year postretention evaluation of orthodontically treated patients. Am J Orthod 1985;87(3):175-186. DOI: 10.1016/0002-9416(85)90038-7.

8. Ferreira FPC, Almeida RR, Torres FC, et al. Evaluation of the stability of open bite treatment using a removable appliance with palatal crib combined with high-pull chincup. Dent Press J Orthod 2012;17(6): 52-60. DOI: 10.1590/S2176-94512012000600014.

9. Huang GJ, Justus R, Kennedy DB, et al. Stability of anterior openbite treated with crib therapy. Angle Orthod 1990;60(1):17-24. DOI: 10.1043/0003-3219(1990)0602.0.CO;2; discussion 25-6.

10. Dias FA, Assis Urnau FD, Pedron Oltramari PV, et al. Stability of early treatment of anterior open bite: clinical performance of bonded lingual spurs. J Orthod 2019;46(1):68-73. DOI: 10.1177/1465312519827601.

11. Henriques JFC, Janson GDRP, Almeida RRD, et al. Mordida aberta anterior: a importância da abordagem multidisciplinar e considerações sobre etiologia, diagnóstico e tratamento. Apresentação de um caso clínico. Revista Dental Press de Ortodontia e Ortopedia Facial 2000;5(3):29-36.

12. Canuto LF, Janson G, de Lima NS, et al. Anterior open-bite treatment with bonded vs conventional lingual spurs: a comparative study. Am J Orthod Dentofacial Orthop 2016;149(6):847-855. DOI: 10.1016/j. ajodo.2015.11.026.

13. Rossato PH, Fernandes TMF, Urnau FDA, et al. Dentoalveolar effects produced by different appliances on early treatment of anterior open bite: a randomized clinical trial. Angle Orthod 2018;88(6):684-691. DOI: 10.2319/101317-691.1.

14. Torres FC, Almeida RR, Almeida-Pedrin RR, et al. Dentoalveolar comparative study between removable and fixed cribs, associated to chincup, in anterior open bite treatment. J Appl Oral Sci 2012;20(5):531-537. DOI: 10.1590/s1678-77572012000500007.

15. Cassis MA, de Almeida RR, Janson G, et al. Treatment effects of bonded spurs associated with high-pull chincup therapy in the treatment of patients with anterior open bite. Am J Orthod Dentofacial Orthop 2012;142(4):487-493. DOI: 10.1016/j.ajodo.2012.04.022.

16. Iscan HN, Dincer M, Gultan A, et al. Effects of vertical chincap therapy on the mandibular morphology in open-bite patients. Am J Orthod Dentofacial Orthop 2002;122(5):506-511. DOI: 10.1067/ $\bmod .2002 .128643$.

17. Leite JS, Matiussi LB, Salem AC, et al. Effects of palatal crib and bonded spurs in early treatment of anterior open bite: a prospective randomized clinical study. Angle Orthod 2016;86(5):734-739. DOI: 10.2319/031815-170.1.

18. Parker $\mathrm{JH}$. The interception of the open bite in the early growth period. Angle Orthod 1971;41(1):24-44. DOI: 10.1043/00033219(1971)0412.0.CO;2.

19. Greenlee GM, Huang GJ, Chen SSH, et al. Stability of treatment for anterior open-bite malocclusion: a meta-analysis. Am J Orthod Dentofacial Orthop 2011;139(2):154-169. DOI: 10.1016/j. ajodo.2010.10.019.

20. Slaviero T, Fernandes TMF, Oltramari-Navarro PVP, et al. Dimensional changes of dental arches produced by fixed and removable palatal cribs: a prospective, randomized, controlled study. Angle Orthod 2017;87(2):215-222. DOI: 10.2319/060116-438.1.

21. Watson WG. Open-bite-a multifactorial event. Am J Orthod 1981;80(4):443-446. DOI: 10.1016/0002-9416(81)90179-2.

22. Feres MF, Abreu LG, Insabralde NM, et al. Effectiveness of open bite correction when managing deleterious oral habits in growing children and adolescents: a systematic review and meta-analysis. Eur J Orthod 2017;39(1):31-42. DOI: 10.1093/ejo/cjw005.

23. Pedrin F, Almeida MR, Almeida RR, et al. A prospective study of the treatment effects of a removable appliance with palatal crib combined with high-pull chincup therapy in anterior open-bite patients. Am J Orthod Dentofacial Orthop 2006;129(3):418-423. DOI: 10.1016/j.ajodo.2005.04.035.

24. Torres F, Almeida RR, de Almeida MR, et al. Anterior open bite treated with a palatal crib and high-pull chin cup therapy. A prospective randomized study. Eur J Orthod 2006;28(6):610-617. DOI: 10.1093/ ejo/cjl053.

25. Silva Filho $O$, Chaves $A$, Almeida R. Efeitos terapêuticos suscitados pelo uso da grade palatina: um estudo cefalométrico. Rev Soc Paranaense Ortod 1995;1(1):9-15.

26. Moyers R, Enlow D. Crescimento do esqueleto craniofacial Moyers RE. Ortodontia. 4a ed., Rio de Janeiro: Guanabara Koogan; 1991. pp. 33-58.

27. Johnson E, Larson B. Thumb-sucking: literature review. ASDC J Dentis Child 1993;60(4):385-391.

28. Bayardo RE, Mejia J, Orozco S, et al. Etiology of oral habits. ASDC J Dentis Child 1996;63(5):350-353.

29. Vanderas AP, Voila P, Papagiannoulis L. Urinary catecholamines as a measure of emotional stress in children with a digit-sucking habit: a preliminary study. ASDC J Dentis Child 2001;68(3):179-182, 50, 52.

30. Leme $M$, Barbosa $T$, Castelo $P$, et al. Associations between psychological factors and the presence of deleterious oral habits in children and adolescents. J Clin Pediat Dentis 2014;38(4):313-317. DOI: $10.17796 /$ jcpd.38.4.c48238322205466w. 